\title{
BAURAN PEMASARAN JASA PENGARUH TERHADAP KEPUASAN KONSUMEN PT. NUSA TONGKAINA WISATA TIRTA (NTWT) MANADO
}

\author{
Agus Supandi Soegoto \\ Dosen Jurusan Manajemen Univ. Sam Ratulangi Manado
}

\begin{abstract}
Abstrak
Penelitian ini bertujuan untuk mengetahui pengaruh produk, tempat, harga, promosi, proses, layanan pelanggan dan orang terhadap kepuasan konsumen PT. Nusa Tongkaina Wisata Tirta. Hipotesis penelitian: "diduga strategi bauran pemasaran jasa berpengaruh terhadap kepuasan konsumen".

Metode analisis yang digunakan adalah regresi linear berganda, korelasi berganda, dan koefisien determinasi. Alat uji hipotesis yang digunakan yaitu uji $F$ dan uji t. Penelitian ini menggunakan 50 responden sebagai sampel. Hasil jawaban diolah dengan menggunakan program SPSS.

Hasil regresi linear berganda pada model 1 diperoleh persamaan $Y=-7,816+0,298 \mathrm{pro}+0,306 \mathrm{hrg}+$ $0,292 \mathrm{prm}+0,102 \mathrm{tpt}+9,224 \mathrm{prs}+3,731$ lay.pel $+0,121$ org, model 2 diperoleh persamaan $Y=-6,504+0,334 \mathrm{pro}$ $+0,270 \mathrm{hrg}+0,317 \mathrm{prm}+0,153 \mathrm{tpt}+8,958 \mathrm{prs}+4,808$ lay.pel. Regresi model 3 diperoleh persamaan $Y=-6,293$ $+0,334$ pro $+0,277 \mathrm{hrg}+0,332 \mathrm{prm}+0,169 \mathrm{tpt}+8,958 \mathrm{prs}$, dan model 4 diperoleh persamaan $\mathrm{Y}=-4,054+$ $0,328 \mathrm{pro}+0,243 \mathrm{hrg}+0,362 \mathrm{prm}+0,199$ tpt. Korelasi (R) pada model 4 sebesar 0,930.

Koefisien determinasi sebesar 0,866 dapat diartikan bahwa besarnya kontribusi produk, harga, promosi dan tempat terhadap kepuasan konsumen sebesar $86,6 \%$. Hasil pengujian uji $t$ (parsial), menunjukan thitung untuk variabel produk sebesar 3,523, harga sebesar 2,274, promosi sebesar 3,808, untuk tempat sebesar 2,373 yang keseluruhanya lebih besar $t_{\text {tabel }}$ yaitu 1,684 artinya keempat variabel ini berpengaruh terhadap nilai variabel dependen (kepuasan konsumen), Ha diterima. Nilai $F_{\text {hitung }}$ dalam penelitian ini sebesar 72,523 lebih besar dari nilai $F_{\text {tabel }}$ sebesar 2,61 pada $\alpha=0,05$ ini berarti Ho ditolak dan Ha diterima. Hal ini menunjukan bahwa variabel produk, harga, promosi dan tempat bersama-sama mempunyai pengaruh yang signifikan terhadap kepuasan konsumen.

Perusahaan harus memperhatikan bauran pemasaran jasa dengan elemen-elemenya, dengan penerapan strategi bauran pemasaran jasa yang lebih baik, diharapkan jasa yang mereka jual dapat memberikan kepuasan bagi konsumen, dengan tidak mengabaikan faktor lain yang tidak di teliti dalam penelitian ini.
\end{abstract}

\section{PENDAHULUAN}

\subsection{Latar Belakang}

Bisnis jasa dalam kondisi lingkungan yang bergejolak relatif diminati oleh para pelaku bisnis karena jasa memiliki fleksibilitas diminati, maka jumlah perusahaan jasa dari berbagai skala dan sub sektor bisnis relatif besar sehingga menambah tingkat persaingan. Persaingan itu pula dipertajam oleh sangat cepatnya pergeseran tuntutan konsumen, oleh karena itu kelangsungan hidup sebuah perusahaan sangat tergantung pada kepuasan para konsumenya disatu sisi dan kemampuan menghasilkan laba disisi yang lain. Adalah tidak mungkin, jika sebuah perusahaan mampu memuaskan kebutuhan konsumenya, namun tidak mampu menghasilkan laba, akan tetap eksis dan makin berkembang jika kedua hal tersebut dicapai secara simultan dan ini yang perlu disadari oleh manajemen setiap perusahaan.

Mengingat semakin ketatnya persaingan karena semakin banyak perusahaan yang terlibat dalam pemenuhan kebutuhan dan keinginan konsumen, menyebabkan perusahaan harus menempatkan orientasi pada kepuasan konsumen sebagai tujuan utama. Dalam situasi demikian setiap perusahaan yang bergerak dibidang jasa harus dapat menentukan strategi yang tepat guna. Bauran pemasaran jasa adalah salah satu strategi yang diterapkan perusahaan untuk pemenuhan kebutuhan dan keinginan sehingga dapat memberikan kepuasan bagi konsumen. Bauran pemasaran jasa merupakan pengembangan dari bauran pemasaran (marketing mix) yang terdiri dari tujuh variable yaitu: Produk, Harga, Promosi, 
Tempat, Orang, Proses, dan Layanan Pelanggan (customer service).

PT. Nusa Tongkaina Wisata Tirta atau dalam hal ini Thalassa Dive Centre yang menjadi objek penelitian penulis sebagai suatu perusahaan jasa yang bergerak di bidang penyewaan alat-alat selam dan tempat belajar menyelam, menyadari bahwa betapa pentingnya penerapan strategi bauran pemasaran jasa dalam perusahaan.

Bauran pemasaran yang di jalankan PT. Nusa Tongkaina Wisata Tirta secara umum dapat dikatakan berhasil, hal ini dapat terlihat dari adanya peningkatan jumlah konsumen yang menyewa alat selam dari tahun ke tahun.

Tabel 1.1. Data konsumen yang menyewa alat selam berdasarkan asal negara dari tahun 2006-2009

\begin{tabular}{|l|c|c|c|c|}
\hline \multirow{2}{*}{ Asal Negara } & \multicolumn{4}{|c|}{ Tahun (Jumlah Konsumen) } \\
\cline { 2 - 5 } & $\mathbf{2 0 0 6}$ & $\mathbf{2 0 0 7}$ & $\mathbf{2 0 0 8}$ & $\mathbf{2 0 0 9}$ \\
\hline Eropa & 1820 & 3850 & 4120 & 4378 \\
\hline Jepang & 2950 & 3005 & 3185 & 3215 \\
\hline Inggris & 1650 & 2850 & 3425 & 3575 \\
\hline Amerika & 720 & 2285 & 2455 & 2250 \\
\hline $\begin{array}{l}\text { Expatriat } \\
\text { Indonesia }\end{array}$ & 450 & 1245 & 1895 & 1990 \\
\hline $\begin{array}{l}\text { Lain-Lain } \\
\text { (Campuran) }\end{array}$ & 856 & 980 & 1115 & 1220 \\
\hline Total & 8446 & 14215 & 16195 & 16628 \\
\hline
\end{tabular}

Sumber: PT. Nusa Tongkaina Wisata Tirta. Tahun 2010

Tabel 1.1 diatas menjelaskan tentang perkembangan jumlah konsumen yang menyewa alat selam berdasarkan asal negara dari tahun 2006 sampai pada tahun 2009. Adanya peningkatan yang sangat signifikan terjadi antara tahun 2006 ke tahun 2007, dimana pada tahun 2006 total jumlah konsumen yang menyewa alat selam yaitu 8.446 orang dan meningkat pesat pada tahun 2007, yaitu menjadi 14.215 atau sekitar 68 $\%$. Diperkirakan minimnya jumlah konsumen yang menyewa alat selam pada tahun 2006 dikarenakan promosi yang masih kurang gencar dilaksanakan oleh pihak perusahaan.

Secara keseluruhan jumlah orang/konsumen yang menyewa alat selam di Thalasa Dive Centre mengalami peningkatan dari tahun ke tahun. Pada tahun 2006 jumlah konsumen yang menyewa alat selam sebesar 8.446 orang, tahun 2007 sebesar 14.215 orang, tahun 2008 sebesar 16.195 orang dan pada tahun 2009 sebesar 16.628 orang. Jumlah penyewaan dari tahun 2006-2009 meningkat sebesar 8.182 orang yang menyewa alat selam.

\subsection{Permasalahan}

Dari penjelasan latar belakang diatas maka penulis mengangkat suatu permasalahan yaitu

"Bagaimana pengaruh bauran pemasaran jasa terhadap kepuasan konsumen PT. Nusa Tongkaina Wisata Tirta ?"

\subsection{Tujuan Penelitian}

Penelitian ini bertujuan untuk mengetahui pengaruh bauran pemasaran jasa terhadap kepuasan konsumen pada PT. Nusa Tongkaina Wisata Tirta Manado.

\section{KERANGKA PEMIKIRAN}

\subsection{Pemasaran, dan Manajemen Pemasaran}

Kotler dan Armstrong (2003 : 9) pemasaran adalah suatu proses sosial dan manajerial dimana individu dan kelompok mendapatkan kebutuhan dan keinginan mereka dengan menciptakan, menawarkan dan bertukar sesuatu yang bernilai dengan pihak lain. Kartajaya, dkk (2002 : 11) pamasaran adalah sebuah disiplin bisnis yang strategis yang mengarahkan proses penciptaan, penawaran dan perubahan nilai dari suatu inisiator kepada stakeholdersnya. ("Marketing is a strategic business discipline that directs the process of creating, offering, and changing valuae from one insitiator to its stakeholders").

Boyd, Walker, dan Larreche (2000： 4) mengatakan bahwa manejemen pemasaran merupakan proses menganalisis, merencanakan, mengkoordinasikan dan mengendalikan program-program yang mencakup pengkosepan, penetapan harga, promosi, dan distribusi dari produk, jasa dan gagasan yang dirancang untuk menciptakan dan memelihara pertukaran yang menguntungkan dengan pasar sasaran untuk mencapai tujuan perusahaan.

Kotler dan Keller (2007: 6) menyatakan manajemen pemasaran sebagai seni dan ilmu memilih pasar sasaran dan mendapatkan, menjaga, dan menumbuhkan pelanggan dengan menciptakan menyerahkan dan 
mengkomunikasikan nilai pelanggan yang unggul. Boyd, Walker dan Larrache (2000: 29) mendefinisikan strategi sebagai pola fundamental dari tujuan sekarang dan yang direncanakan, pengerahan sumberdaya, dan interaksi dari organisasi dengan pasar, pesaing dan faktor lingkungan lain. Fokus utama dari strategi pemasaran adalah mengalokasikan dan mengkoordinasi sumberdaya dalam kegiatan pemasaran untuk mencapai tujuan perusahaan didalam pasar produk spesifik.

\subsection{Bauran Pemasaran (Marketing Mix)}

Menurut Payne (2001: 31) bauran pemasaran jasa merupakan konsep bauran pemasaran yang dikembangkan untuk sector jasa yang terdiri dari variabel atau unsur-unsur yang membentuk program pemasaran suatu organisasi. Selanjutnya ada tiga unsur penting didalam mengembangkan program bauran pemasaran untuk jasa, yaitu: proses, orang, dan layanan pelanggan (customer service)

Bauran pemasaran yang diperluas untuk jasa dapat ditunjukan pada Gambar 2.1.

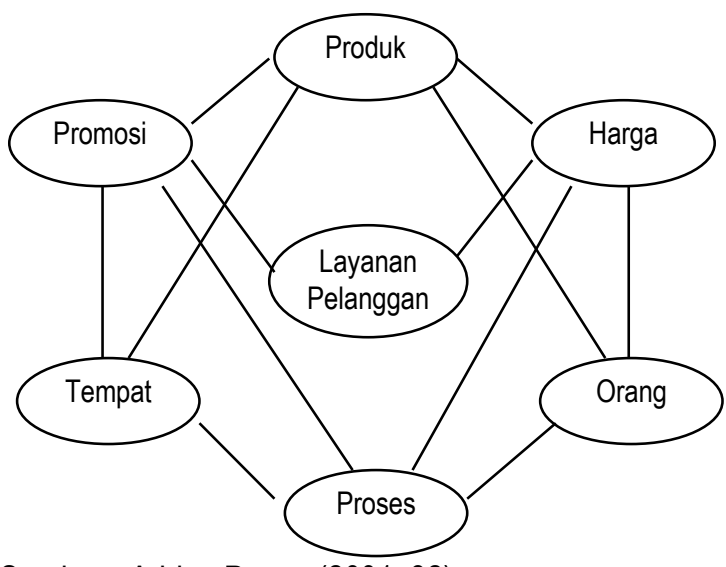

Sumber : Adrian Payne (2001: 32)

Gambar 2.1 Bauran Pemasaran Jasa

Gambar 2.1 menunjukan hubungan antara bauran pemasaran yaitu produk, harga, promosi, tempat dan tiga unsur tambahan dalam program pemasaran untuk jasa yaitu layanan pelanggan, orang dan proses, ini merupakan unsur-unsur kunci dalam bauran pemasaran.

\subsection{Kepuasan Konsumen}

Kepuasan pelanggan (konsumen) bagi perusahaan merupakan sesuatu yang harus diupayakan terus-menerus, karena hal tersebut merupakan kunci sukses jangka panjang perusahaan. Jika tingkat kepuasan pelanggan semakin tinggi, maka akan memberikan manfaat antara lain adalah memberikan dasar yang baik bagi pembelian ulang dan terciptanya loyalitas pelanggan. Pembelian ulang dan loyalitas pelanggan kepada perusahaan merupakan jalan untuk meraih laba yang semakin besar.

Schermerhorn (1993 : 94), berpendapat bahwa pada dasarnya tujuan dari suatu organisasi bisnis adalah memproduksi barang atau jasa yang memuaskan kebutuhan pelangganya. Dengan kata lain perusahaan berusaha untuk menciptakan para pelanggan yang merasa puas. Untuk dapat menciptakan para pelanggan yang merasa puas, manajemen perusahaan harus mengetahui hal-hal yang menyebabkan terciptanya kepuasan pelanggan. Menurut Tjiptono (1997 : 25), terciptanya kepuasan pelanggan dapat memberikan beberapa manfaat, diantaranya hubungan antara perusahaan dengan pelanggan menjadi harmonis, memberikan dasar yang baik bagi pembelian ulang dan terciptanya loyalitas pelanggan, dan memberikan rekomendasi dari mulut ke mulut yang menguntungkan bagi perusahaan.

Kata 'kepuasan' (satisfaction) berasal dari bahasa Latin "satis" (artinya cukup baik, memadai) dan "facio" (melakukan atau membuat). Secara sederhana kepuasan dapat diartikan sebagai 'upaya pemenuhan sesuatu' atau 'membuat sesuatu memadai'.

Kepuasan pelanggan menurut Kotler dan Armstrong (2003:10) "Satisfaction is a person's feelings of pleasure or disappointment resulting from company a product's perceived performance (or Outcame) in relation to his or her expectations." Dari penjelasan tersebut menunjukkan bahwa, hasil dari membandingkan antara apa yang di harapkan dengan apa yang dirasakan dari suatu produk akan menghasilkan rasa puas atau kecewa pelanggan.

Pendapat bahwa kepuasan pelanggan merupakan perbandingan antara apa yang diharapkan dan apa yang diperoleh juga dikemukakan oleh Soderlund (2003: 1376) juga "A mental state which results from the customer's 
comparison of (expectation prior to a purchase performance perceptions after a purchase)." Definsi tersebut menjelaskan juga bahwa kepuasan pelanggan merupakan perbandingan antara apa yang diharapkan dari sebuah produk setelah di membeli atau mengkonsumsinya.

Kepuasan sebagai suatu perbandingan antara harapan dan apa yang dirasakan juga dikemukakan oleh Fecikova (2004:57) yang menjelakan bahwa kepuasan pelanggan adalah "a feeling which results from a process of evaluating what was received agains that expected, the purchase decision itself and/or the fulfillment of need/want." Pendapat tersebut menerangkan bahwa kepuasan merupakan perasaan yang dihasilkan dari dari mengevaluasi apa yang dirasakan dibandingkan dengan harapannya, yang berkaitan dengan keinginan dan kebutuha dari pelanggan tersebut pada sebuah produk atau layanan.

Lebih lanjut Shankar et.al (2003:154) menjelaskan bahwa kepuasan pelang-gan merupakan "The perception of pleasurable fulfillment of a service, and loyalty as deep commitment to the service provider." Pengertian tersebut menunjukkan bahwa kepuasan pelanggan lebih mengarah pada sikap dan perilaku loyal, atau ditunjukkan oleh komitmen yang tinggi terhadap perusahaan.

Berdasarkan pendapat para pakar tersebut, dapat disimpulkan bahwa kepuasan adalah perasaan senang atau kecewa yang dimiliki seseorang berdasarkan perbandingan antara kenyataan yang diperoleh dengan harapan yang diinginkan oleh pelanggan. Jika barang dan jasa yang dibeli cocok dengan apa yang diharapkan oleh pelanggan, maka akan terdapat kepuasan atau sebaliknya. Bila kenikmatan yang diperoleh pelanggan melebihi harapannya, maka pelanggan akan betul-betul merasa puas dan sudah pasti mereka akan terus mengadakan pembelian ulang serta mengajak teman-teman sehingga itu dapat memberikan keuntungan bagi perusahaan.

\subsection{Hipotesis}

Berdasarkan latar belakang permasalahan dan teori yang dikemukakan sebelumnya maka hipotesa yang perlu dibuktikan adalah:

"Diduga strategi bauran pemasaran jasa yang diterapkan oleh PT. Nusa Tongkaina
Wisata Tirta Manado berpengaruh terhadap kepuasan konsumen".

\section{METODE PENELITIAN}

\subsection{Data dan Sumber Data}

\subsubsection{Data}

Data yang dikumpulkan dalam kaitan penelitian ini adalah:

a. Data kuantitatif merupakan data dalam bentuk angka-angka yang secara langsung diperoleh dari hasil penelitian. Dalam penelitian ini, data kuantitatif yang digunakan adalah jumlah unit produk yang disewa selama periode tahun 20062009.

b. Data kualitatif yang merupakan serangkaian informasi yang didapat dari hasil penelitian yang berupa fakta-fakta verbal atau keterangan saja.

\subsubsection{Sumber Data}

Dari segi sumbernya, data yang digunakan dalam penelitian ini adalah data primer. Data primer yaitu data yang diperoleh melalui pengamatan langsung serta hasil wawancara dengan pimpinan perusahaan dan juga merupakan data yang diperoleh melalui penyebaran daftar pertanyaan kepada para responden

\subsection{Metode Pengumpulan Data}

Metode yang digunakan dalam pengumpulan data dalam penelitian ini yaitu melalui observasi, wawancara dan quesioner.

\subsection{Metode Pengambilan Sampel}

Populasi dari penelitian ini adalah seluruh karakteristik yang berhubungan dengan objek penelitian ini, dalam hal ini adalah seluruh konsumen PT. Nusa Tongkaina Wisata Tirta Manado. Mengingat banyaknya konsumen yang menggunakan jasa tersebut, maka dalam penelitian ini ditetapkan sampel sebanyak 50 orang sebagai responden.

Metode pengambilan sampel yang digunakan dalam penelitian ini adalah teknik purposive sampling. Menurut Durianto (2001 : 33) purposive sampling diambil berdasarkan kriteria yang telah 
dirumuskan terlebih dahulu oleh si peneliti. Selanjutnya, menurut Santoso dan Tjiptono (2002 : 90) teknik purposive sampling merupakan teknik non probability sampling yang memilih orang berdasarkan ciri-ciri khusus yang telah ditentukan.

\subsection{Definisi dan Pengukuran Variabel}

Dalam penelitian ini menggunakan variabel bebas $(X)$ dan variable terikat $(Y)$. adapun variabelvariabel yang diukur dalam penelitian ini adalah:

a. Bauran pemasaran jasa dan

b. Kepuasan konsumen

\subsection{Metode Analisis}

Metode analisa yang digunakan dalam penelitian ini adalah regresi linier berganda, koefisien korelasi berganda, koefisien determinasi berganda, uji parsial dan uji F:

\subsubsection{Regresi Linear Berganda}

Regresi linear berganda adalah regresi dimana variabel terikatnya $(\mathrm{Y})$ dihubungkan I dijelaskan lebih dari satu variabel. Analisis regresi digunakan untuk menemukan derajat ketergantungan satu variabel terhadap satu variabel lainya atau lebih. Analisis regresi ini memungkinkan kita untuk menarik kesimpulan atas dampak dari variabel-variabel independen terhadap variabel dependen. Metode ini dipilih karena penulis ingin mengetahui seberapa besar faktor produk, harga, promosi, tempat, proses, layanan pelanggan dan orang berpengaruh terhadap kepuasan konsumen.

Persamaan regresi linear berganda adalah sebagai berikut (Hasan, 2003 : 269):

\section{$X_{5}+b_{6} X_{6}+b_{7} X_{7}+e$}

$$
Y=a+b_{1} X_{1}+b_{2} X_{2}+b_{3} X_{3}+b_{4} X_{4}+b_{5}
$$

dimana : $X_{1}, X_{2}, X_{3}, X_{4}, X_{5}, X_{6}, X_{7}$ merupakan variabel bebas, yaitu:

$$
X_{1}=\text { Produk, } X_{2}=\text { Harga }, X_{3}=\text { Promosi, }
$$

$X_{4}=$ Tempat,$X_{5}=$ Proses,$\quad X_{6}=$ Layanan

Pelanggan, $X_{7}=$ Orang

$$
\begin{aligned}
& Y \text { merupakan variabel tergantung } \\
& e=\text { kesalahan penganggu } \\
& a=\text { intercept } \\
& b=\text { koefisien regresi }
\end{aligned}
$$

berdasarkan persamaan di atas, penulis membuat suatu model yang menghubungkan kepuasan konsumen $(Y)$ dengan unsur-unsur bauran pemasaran jasa $\left(X_{1}, X_{2}, \ldots X_{7}\right)$ yaitu :

$\mathrm{KK}=\mathrm{f}$ (pro,hrg,prm,tpt, prs, lay. kon, org)

$K K=Z_{0}+Z_{1}$ pro $+Z_{2}$ hrg $+Z_{3}$ prm $+Z_{4}$ tpt + $Z_{5}$ prs $+Z_{6}$ lay.pel $+Z_{7}$ org

$$
\begin{aligned}
\text { Dimana : KK } & =\text { Kepuasan Konsumen } \\
\text { Pro } & =\text { produk } \\
\text { Hrg } & =\text { harga } \\
\text { Prm } & =\text { promosi } \\
\text { Tpt } & =\text { tempat } \\
\text { Prs } & =\text { proses } \\
\text { Org } & =\text { orang } \\
Z_{0} & =\text { intercept } \\
Z_{1} & =\text { koefisien regresi } \\
\text { e } & =\text { kesalahan pengganggu }
\end{aligned}
$$

\subsubsection{Koofisien Korelasi berganda ( $r$ )}

Hasan (2003: 263), Korelasi linear berganda merupakan alat ukur mengenai hubungan yang terjadi antara variabel terikat $(Y)$ dengan dua atau lebih variabel bebas $\left(X_{1}, X_{2}, X_{3}, \ldots X n\right)$. Dengan korelasi linear berganda ini, keeratan atau kuat tidaknya hubungan antara variabel-variabel tersebut dapat diketahui. Keeratan hubungan ini dinyatakan dengan istilah koefisien korelasi linear berganda yang merupakan indeks atau angka yang digunakan untuk mengukur keeratan hubungan antara tiga variabel atau lebih.

Persamaan dari koefisien korelasi linear berganda adalah sebagai berikut :

$$
R_{y 12}=\sqrt{\frac{\mathrm{r}^{2}{ }_{\mathrm{Y} 1}+\mathrm{r}^{2}{ }_{\mathrm{Y} 2}+\mathrm{r}^{2}{ }_{\mathrm{Y} 3}+\mathrm{r}^{2} \mathrm{y} 4-2 \mathrm{r}_{\mathrm{y} 1} \cdot \mathrm{r}_{\mathrm{y} 2} \cdot \mathrm{r}_{\mathrm{y} 3} \cdot \mathrm{r}_{\mathrm{y} 4} \cdot \mathrm{r}_{12}}{1-\mathrm{r}^{2}{ }_{12}}}
$$

Dimana :

$\mathrm{R}_{\mathrm{Y} .12}=$ koefisien korelasi linear berganda

$r_{Y_{1}}=$ koefisien korelasi variabel $Y_{\text {dan }} \mathrm{X}_{1}$

$r_{Y_{2}}=$ koefisien korelasi variabel $Y$ dan $X_{2}$

$r_{Y_{3}}=$ koefisien korelasi variabel $Y$ dan $X_{3}$

$r_{Y_{4}}=$ koefisien korelasi variabel $Y$ dan $X_{4}$

$r_{Y_{5}}=$ koefisien korelasi variabel $Y$ dan $X_{5}$

$r_{Y_{6}}=$ koefisien korelasi variabel $Y$ dan $X_{6}$

$\mathrm{r}_{\mathrm{Y} 7}=$ koefisien korelasi variabel $\mathrm{Y}_{\mathrm{Oan}} \mathrm{X}_{7}$

$r_{12}=$ koefisien korelasi variabel $X$

Untuk mengukur kuatnya hubungan antara variabel-variabel bebas secara bersama-sama terhadap variable tidak bebas kriteria penilaian adalah sebagai berikut (Supranto, $1993:$ 208)

$<0,20$ dapat diabaikan

$0,20-0,40$ korelasi rendah

$0,40-0,70$ korelasi subtansial

$0,70-1,00$ derajat asosiasi tinggi 


\subsubsection{Koefisien Determinasi berganda $\left(\mathbf{R}^{2}\right)$}

Menurut Arsyad (1994;186), koefisien determinasi berganda adalah angka yang menunjukkan proporsi variable dependen yang dijelaskan oleh variasi variabel independen. Artinya $\mathrm{R}^{2}$ menunjukkan seberapa besar sumbangan variabel independen $(X)$ terhadap naik turunnya variabel dependen $(Y)$.

\subsubsection{Koefisien Korelasi Parsial}

Hasan (2003 : 268), Koefisien korelasi parsial adalah indeks atau angka yang digunakan untuk mengukur keeratan hubungan antara dua variabel jika variabel lainya konstan, pada hubungan yang melibatkan lebih dari dua variabel.

\subsubsection{Pengujian Hipotesa dengan Uji $F$}

Menurut Algifari $(1997 ; 163)$, pengujian ini dilakukan untuk mengetahui apakah semua variabel independen secara bersama-sama (simultan) dapat berpengaruh terhadap variabel dependen. Pengujian dilakukan menggunakan distribusi $F$ dengan membandingkan antara nilai kritis $\mathrm{F}$ dengan nilai $\mathrm{F}_{\text {test }}$ yang terdapat dari hasil perhitungan.

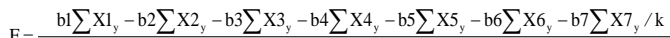
$\mathrm{F}=\frac{\mathrm{b} 2 \mathrm{~b} 1 \sum \mathrm{X} 1_{\mathrm{y}}-\mathrm{b} 2 \sum \mathrm{X} 2_{\mathrm{y}}-\mathrm{b} 3 \sum \mathrm{X} 3_{\mathrm{y}}-\mathrm{b} 4 \sum \mathrm{X} 4_{\mathrm{y}}-\mathrm{b} 5 \sum \mathrm{X} 5_{\mathrm{y}}-\mathrm{b} 6 \sum \mathrm{X} 6_{\mathrm{y}}-\mathrm{b} 7 \sum \mathrm{X} 7_{\mathrm{y}} / \mathrm{n}}{\mathrm{y}}$ dimana : $k=$ variabel

$$
\mathrm{n}=\text { ukuran sampel }
$$

Apabila $F_{\text {hitung }}<\mathrm{F}$ table $(\mathrm{n}-\mathrm{k}-1)$ maka $\mathrm{Ho}$ diterima, Ha ditolak

Tetapi jika $F_{\text {hitung }}>F_{\text {table }}(\mathrm{n}-\mathrm{k}-1)$ maka Ho ditolak, Ha diterima

\section{HASIL PENELITIAN DAN PEMBAHASAN}

\subsection{Deskripsi Responden}

Penelitian ini dilakukan terhadap konsumen / pelanggan Thalasa Dive Centre dengan sampel sebanyak 50 orang. Pada penelitian ini penulis mengelompokan responden kedalam kategori berdasarkan jenis kelamin, usia, status pendidikan dan pekerjaan.

\section{a. Responden Menurut Jenis Kelamin}

Berdasarkan tujuan penelitian ini yaitu untuk mengetahui sejauh mana marketing mix berpengaruh terhadap kepuasan konsumen yang menyewa alat selam Thalasa Dive Centre. Maka pada penelitian ini penulis mengambil responden berdasarkan jenis kelamin, karena penulis ingin mengetahui berapa banyak konsumen/pelanggan yang menggunakan jasa sewa alat selam Thalasa Dive Centre berdasarkan jenis kelamin. Dari kuesioner yang dijalankan, maka didapat jumlah responden berdasarkan jenis kelamin berikut ini :

Tabel 4.1 Distribusi Responden Berdasarkan Jenis Kelamin

\begin{tabular}{|l|c|c|}
\hline Jenis Kelamin & Jumlah & Persentase \\
\hline Laki-Laki & 37 & $74 \%$ \\
\hline Perempuan & 13 & $26 \%$ \\
\hline JUMLAH & 50 & $100 \%$ \\
\hline
\end{tabular}

Sumber: Data Olahan, 2010

Dilihat dari jenis kelamin didapati responden yang berjenis kelamin laki-laki sebanyak 37 orang (47 $\%)$ dari 50 orang responden, sedangkan sisanya sebesar 13 orang $(26 \%)$ berjenis kelamin perempuan. Dari data diatas dapat dilihat bahwa laki-laki merupakan responden terbesar yang paling banyak menggunakan jasa Thalasa Dive Centre.

\section{b. Responden Berdasarkan Usia}

Pada penelitian ini juga, penulis ingin mengetahui tanggapan konsumen/pelanggan berdasarkan karakteristik usia responden. Responden yang menggunakan jasa sewa alat selam selam Thalasa Dive Centre paling banyak dapat dilihat pada table 4.2 dibawah ini.

Tabel 4.2 Distribusi Responden Berdasarkan Usia

\begin{tabular}{|l|c|c|}
\hline \multicolumn{1}{|c|}{ Umur } & Jumlah & Persentase \\
\hline $20-29$ Tahun & 7 & $14 \%$ \\
\hline $30-39$ Tahun & 19 & $38 \%$ \\
\hline 40-50 Tahun & 24 & $48 \%$ \\
\hline JUMLAH & 50 & $100 \%$ \\
\hline
\end{tabular}

Sumber: Data Olahan, 2010

Berdasarkan usianya, responden yang masuk kelompok antara 20 tahun sampai 29 tahun berjumlah 7 orang (14\%), responden yang berusia antara 30 tahun sampai 39 berjumlah 19 orang (38 $\%$ ), responden yang berusia 40 tahun sampai 50 tahun berjumlah 24 orang (48\%).

\section{c. Status Pendidikan Responden}

Berdasarkan karakteristik pengambilan sampel, maka penulis mengelompokan responden berdasarkan latar belakang pendidikan. Penulis ingin mengetahui berapa banyak 
konsumen/pelanggan yang menggunakan jasa sewa alat selam Thalasa Dive Centre berdasarkan latar belakang pendidikan.

Tabel 4.3 Distribusi Responden Berdasarkan Latar Belakang Pendidikan

\begin{tabular}{|l|c|c|}
\hline \multicolumn{1}{|c|}{ Umur } & Jumlah & Persentase \\
\hline SMU & 5 & $10 \%$ \\
\hline D3 & 8 & $16 \%$ \\
\hline S1 & 30 & $60 \%$ \\
\hline S2 & 7 & $14 \%$ \\
\hline JUMLAH & 50 & $100 \%$ \\
\hline
\end{tabular}

Sumber: Data Olahan, 2010

Jumlah konsumen berdasarkan latar belakang pendidikan yaitu sebagai berikut, mahasiswa sebesar 30 orang (60 \%) dan sisanya didistribusikan masing-masing pada SMU 5 Orang (10\%), D3 8 orang (16\%) dan pasca Sarjana 7 orang (14\%). Dari tabel diatas jelas bahwa mahasiswa merupakan responden terbesar yang menggunakan jasa Thalasa Dive Centre.

\section{d. Pekerjaan Responden}

Pada penelitian ini, penulis ingin mengetahui seberapa besar kepuasan konsumen berdasarkan pekerjaan. Jumlah responden yang paling banyak menggunakan jasa sewa alat selam dapat dilihat pada table 4.4

Tabel 4.4 Distribusi Responden Berdasarkan Pekerjaan

\begin{tabular}{|l|c|c|}
\hline \multicolumn{1}{|c|}{ Pekerjaan } & Jumlah & Persentase \\
\hline Mahasiswa & 6 & $12 \%$ \\
\hline Karyawan & 18 & $36 \%$ \\
\hline Wiraswasta & 26 & $52 \%$ \\
\hline JUMLAH & 50 & $100 \%$ \\
\hline
\end{tabular}

Sumber: Data Olahan, 2010

Pada penelitian ini penulis lebih menitikberatkan pada wiraswasta sehingga pada data tentang pekerjaan responden, jumlah terbesar ada pada wiraswastawan yaitu 26 orang atau (52\%) dan sisanya didistribusikan pada karyawan dan mahasiswa. Responden yang berstatus karyawan sebanyak 18 orang (36\%), dan responden yang berstatus mahasiswa sebanyak 6 orang atau ( 12 $\%)$.

\subsection{Pembahasan}

Penelitian ini bertujuan untuk mengetahui bagaimana keberadaan produk, harga, promosi, tempat, proses, layanan pelanggan, orang dalam pengaruhnya terhadap kepuasan konsumen pada konsumen atau pelanggan yang menyewa alat selam di Thalasa Dive Centre. Dalam proses analisa data akan dilakukan perhitungan dengan program SPSS (lihat lampiran). Dari hasil pengolahan data pada lampiran dapat diringkas sebagai berikut :

Tabel 4.5 Model 1: Hasil Analisis Regresi Linear Berganda, Koefisien Korelasi dan Determinasi.

\begin{tabular}{|c|l|c|c|c|}
\hline $\begin{array}{c}\text { Variabel } \\
\text { Terikat }(\mathrm{Y})\end{array}$ & $\begin{array}{c}\text { Variabel } \\
\text { Bebas }(\mathrm{X})\end{array}$ & Correlation & t Hitung & Coefficients \\
\hline $\begin{array}{c}\text { Kepuasan } \\
\text { Konsumen }\end{array}$ & Produk & 0,805 & 3,080 & 0,298 \\
\cline { 2 - 5 } & Harga & 0,795 & 2,707 & 0,306 \\
\cline { 2 - 5 } & Promosi & 0,837 & 2,884 & 0,292 \\
\cline { 2 - 5 } & Tempat & 0,778 & 1,038 & 0,102 \\
\cline { 2 - 5 } & Proses & 0,322 & 1,390 & 9,224 \\
\cline { 2 - 5 } & Layanan & 0,661 & 0,506 & 3,731 \\
\cline { 2 - 5 } & Pelanggan & & 1,264 & 0,121 \\
\cline { 2 - 5 } & Orang & 0,684 & & \\
\hline
\end{tabular}

$\begin{array}{ll}\text { Konstanta } & :-7.816 \\ \text { Fhitung } & : 42.793 \\ \text { R. squared } & : 0.877 \text { (Determinasi) } \\ \text { Multiple R } & : 0.936 \text { (Korelasi) }\end{array}$

Dari hasil analisis, diperoleh persamaan regresi linear berganda sebagai berikut :

$Y=-7,816+0,298 \mathrm{pro}+0,306 \mathrm{hrg}+0,292 \mathrm{prm}+$ 0,102 tpt $+9,224 p r s+3,731$ lay.pel $\quad+$ 0,121 org

Untuk mengetahui besarnya kontribusi seluruh variabel bebas $(X)$ terhadap variabel kepuasan konsumen $(Y)$, dapat dilihat dari koefisien determinasinya $\left(R^{2}\right)$. Nilai $R^{2}$ pada penelitian ini sebesar 0,877 dapat diartikan bahwa besarnya kontribusi produk, harga, promosi, tempat, proses, layanan pelanggan, dan orang terhadap kepuasan konsumen sebesar 87,7 \% sedangkan sisanya sebesar $12,3 \%$ dipengaruhi oleh variabel lain yang tidak diteliti dalam penelitian ini.

Hasil perhitungan dengan menggunakan program SPSS diperoleh nilai thitung untuk produk sebesar 3,080 lebih besar dari nilai tabel sebesar 1,684 artinya variabel produk berpengaruh terhadap nilai variabel dependen (kepuasan konsumen), ini berarti Ha diterima. Nilai thitung untuk harga sebesar 2,707 lebih besar dari nilai $t_{\text {tabel sebesar } 1,684 \text { artinya variabel harga }}$ berpengaruh terhadap nilai variabel dependen (kepuasan konsumen), Ha diterima . Nilai thitung untuk promosi sebesar 2,884 lebih besar dari nilai $t_{\text {tabel }}$ sebesar 1,684 artinya variabel promosi berpengaruh terhadap nilai variabel dependen 
(kepuasan konsumen), Ha diterima. Nilai thitung untuk tempat sebesar 1,038 lebih kecil dari nilai $t_{\text {tabel }}$ sebesar 1,684 artinya variabel tempat tidak berpengaruh terhadap nilai variabel dependen (kepuasan konsumen), Ha ditolak. Nilai thitung untuk variabel proses sebesar 1,390 lebih kecil dari nilai $t_{\text {tabel }}$ sebesar 1,684 artinya variabel proses tidak berpengaruh terhadap nilai variabel kepuasan konsumen, nilai thitung untuk variabel layanan pelanggan sebesar 0,506 lebih kecil dari nilai tabel 1,684 artinya variabel layanan pelanggan tidak berpengaruh terhadap kepuasan konsumen. Nilai $t_{\text {tabel }}$ untuk variabel orang sebesar 1,264 lebih kecil dari nilai $t_{\text {tabel }} 1,684$ artinya variabel orang tidak berpengaruh terhadap variabel kepuasan konsumen.

Nilai $F_{\text {hitung }}$ dalam penelitian ini sebesar 42,793 lebih besar dari nilai $F_{\text {tabel }}$ sebesar 2,61 pada $\alpha=0,05$ ini berarti $\mathrm{Ho}$ ditolak dan $\mathrm{Ha}$ diterima. Hal ini menunjukan bahwa variabel produk, harga, promosi, tempat, proses, layanan pelanggan dan orang bersama-sama mempunyai pengaruh yang sangat signifikan terhadap kepuasan konsumen.

Berdasarkan hasil analisis diatas menunjukan variabel tempat, proses, layanan pelanggan dan orang tidak signifikan terhadap kepuasan konsumen. Oleh karena itu, penulis menganalisa kembali data dengan menghilangkan variabel tempat, proses, layanan pelanggan, dan orang. Dari proses analisis data dengan menggunakan program SPSS. Hasil analisa dapat dilihat dari tabel 4.6 berikut ini.

Tabel 4.6 Model 2: Hasil Analisis Regresi Linear Berganda, Koefisien Korelasi dan Determinasi.

\begin{tabular}{|c|l|c|c|c|}
\hline $\begin{array}{c}\text { Variabel } \\
\text { Terikat }(\mathrm{Y})\end{array}$ & $\begin{array}{c}\text { Variabel } \\
\text { Bebas }(\mathrm{X})\end{array}$ & Correlation & t Hitung & Coefficients \\
\hline \multirow{2}{*}{$\begin{array}{l}\text { Kepuasan } \\
\text { Konsumen }\end{array}$} & Produk & 0,805 & 3,587 & 0,334 \\
\cline { 2 - 5 } & Harga & 0,795 & 2,448 & 0,270 \\
\cline { 2 - 5 } & Promosi & 0,837 & 3,170 & 0,317 \\
\cline { 2 - 5 } & Tempat & 0,778 & 1,703 & 0,153 \\
\cline { 2 - 5 } & Proses & 0,322 & 1,302 & 8,679 \\
\cline { 2 - 5 } & Layanan & 0,661 & 0,652 & 4,808 \\
\hline
\end{tabular}

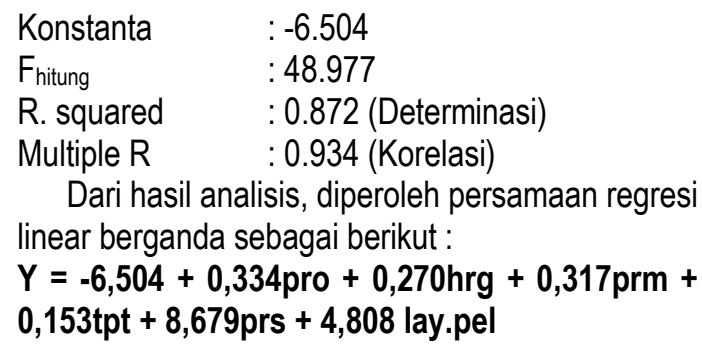

Korelasi antara variabel produk dengan kepuasan konsumen sangatlah signifikan, hal ini dapat dilihat dari tabel korelasi yang menunjukan angka sebesar 0,805 yang artinya, hubungan variabel produk terhadap kepuasan konsumen memiliki derajat asosiasi yang tinggi. Korelasi yang berderajat asosiasi yang tinggi juga dimiliki variabel harga, dimana hal ini ditunjukan oleh angka korelasi sebesar 0,795. dan korelasi yang berderajat asosiasi paling tinggi diantara 7 variabel adalah variabel promosi yaitu angka korelasi sebesar 0,837 . korelasi yang berderajat asosiasi yang tinggi juga dimiliki oleh variabel tempat, dimana dapat dilihat angka korelasi sebesar 0,778. sebaliknya variabel proses yang memiliki hubungan yang sangat rendah terhadap kepuasan konsumen dengan tingkat korelasi sebesar 0,322. Variabel layanan pelanggan dengan tingkat korelasi yang substansial yaitu sebesar 0,661. Secara keseluruhan ke tujuh variabel ini mempunyai pengaruh yang sangat signifikan terhadap kepuasan konsumen hal ini ditunjukan oleh angka korelasi (R) sebesar 0,934 yang artinya, hubungan variabel independen yaitu produk, harga, promosi, tempat, proses, layanan pelanggan, dan orang mempengaruhi variabel dependen yaitu kepuasan konsumen sebesar $93,4 \%$.

Untuk mengetahui besarnya kontribusi seluruh variabel bebas $(X)$ terhadap variabel kepuasan konsumen $(Y)$, dapat dilihat dari koefisien determinasinya $\left(R^{2}\right)$. Nilai $R^{2}$ pada penelitian ini sebesar 0,872 dapat diartikan bahwa besarnya kontribusi produk, harga, promosi, tempat, proses, layanan pelanggan terhadap kepuasan konsumen sebesar $87,2 \%$ sedangkan sisanya sebesar 12,8 $\%$ dipengaruhi oleh variabel lain yang tidak diteliti dalam penelitian ini.

Hasil perhitungan dengan menggunakan program SPSS diperoleh nilai thitung untuk produk sebesar 3,587 lebih besar dari nilai tabel sebesar 1,684 artinya variabel produk berpengaruh terhadap nilai variabel dependen (kepuasan konsumen), ini berarti $\mathrm{Ha}$ diterima. Nilai thitung untuk harga sebesar 2,448 lebih besar dari nilai tabel sebesar 1,684 artinya variabel harga berpengaruh terhadap nilai variabel dependen (kepuasan konsumen), Ha diterima . Nilai thitung untuk promosi sebesar 3,170 lebih besar dari nilai $t_{\text {tabel }}$ sebesar 1,684 artinya variabel promosi berpengaruh terhadap nilai variabel dependen

Strategic, Volume 9, Nomor 17, Februari 2010 
(kepuasan konsumen), Ha diterima. Nilai thitung untuk tempat sebesar 1,703 lebih besar dari nilai $t_{\text {tabel }}$ sebesar 1,684 artinya variabel tempat berpengaruh terhadap nilai variabel dependen (kepuasan konsumen), Ha diterima. Nilai thitung untuk variabel proses sebesar 1,302 lebih kecil dari nilai tabel sebesar 1,684 artinya variabel proses tidak berpengaruh terhadap nilai variabel kepuasan konsumen. Nilai tabel untuk variabel layanan pelanggan sebesar 0,652 lebih kecil dari nilai tabel 1,684 artinya variabel layanan pelanggan tidak berpengaruh terhadap variabel kepuasan konsumen.

Nilai $F_{\text {hitung }}$ dalam penelitian ini sebesar 48,587 lebih besar dari nilai $F_{\text {tabel }}$ sebesar 2,61 pada $\alpha=$ 0,05 ini berarti Ho ditolak dan Ha diterima. Hal ini menunjukan bahwa variabel produk, harga, promosi, tempat, proses, layanan pelanggan dan orang bersama-sama mempunyai pengaruh yang sangat signifikan terhadap kepuasan konsumen.

Berdasarkan hasil analisis diatas menunjukan variabel proses, layanan pelanggan tidak signifikan terhadap kepuasan konsumen. Oleh karena itu, penulis menganalisa kembali data dengan menghilangkan satu-persatu variabel-variabel tersebut untuk melihat hasil hipotesa baik uji $t$ maupun uji F. Dari proses analisis data dengan menggunakan program SPSS. Hasil analisa dapat dilihat dari tabel 4.7 berikut ini.

Tabel 4.7 Model 3: Hasil Analisis Regresi Linear Berganda, Koefisien Korelasi dan Determinasi.

\begin{tabular}{|c|l|c|c|c|}
\hline $\begin{array}{c}\text { Variabel } \\
\text { Terikat }(\mathrm{Y})\end{array}$ & $\begin{array}{c}\text { Variabel } \\
\text { Bebas }(\mathrm{X})\end{array}$ & Correlation & t Hitung & Coefficients \\
\hline Kepuasan & Produk & 0,805 & 3,616 & 0,334 \\
\cline { 2 - 5 } Konsumen & Harga & 0,795 & 2,548 & 0,277 \\
\cline { 2 - 5 } & Promosi & 0,837 & 3,437 & 0,332 \\
\cline { 2 - 5 } & Tempat & 0,778 & 1,963 & 0,169 \\
\cline { 2 - 5 } & Proses & 0,322 & 1,355 & 8,958 \\
\hline
\end{tabular}

Konstanta $\quad:-6.293$

F hitung $: 59.469$

R. squared $\quad: 0.871$ (Determinasi)

Multiple R : 0.933 (Korelasi)

Dari hasil analisis, diperoleh persamaan regresi linear berganda sebagai berikut :

$\mathrm{Y}=-6,293+0,334 \mathrm{pro}+0,277 \mathrm{hrg}+0,332 \mathrm{prm}+$ 0,169 tpt + 8,958prs

Korelasi antara variabel produk dengan kepuasan konsumen sangatlah signifikan, hal ini dapat dilihat dari tabel korelasi yang menunjukan angka sebesar 0,805 yang artinya, hubungan variabel produk terhadap kepuasan konsumen memiliki derajat asosiasi yang tinggi. Korelasi yang berderajat asosiasi yang tinggi juga dimiliki variabel harga, dimana hal ini ditunjukan oleh angka korelasi sebesar 0,795. dan korelasi yang berderajat asosiasi paling tinggi diantara 7 variabel adalah variabel promosi yaitu angka korelasi sebesar 0,837 . korelasi yang berderajat asosiasi yang tinggi juga dimiliki oleh variabel tempat, dimana dapat dilihat angka korelasi sebesar 0,778. sebaliknya variabel proses yang memiliki hubungan yang sangat rendah terhadap kepuasan konsumen dengan tingkat korelasi sebesar 0,322. Secara keseluruhan ke tujuh variabel ini mempunyai pengaruh yang sangat signifikan terhadap kepuasan konsumen hal ini ditunjukan oleh angka korelasi (R) sebesar 0,933 yang artinya, hubungan variabel independen yaitu produk, harga, promosi, tempat, proses, layanan konsumen, dan orang mempengaruhi variabel dependen yaitu kepuasan konsumen sebesar $93,3 \%$.

Untuk mengetahui besarnya kontribusi seluruh variabel bebas $(X)$ terhadap variabel kepuasan konsumen $(Y)$, dapat dilihat dari koefisien determinasinya $\left(R^{2}\right)$. Nilai $R^{2}$ pada penelitian ini sebesar 0,871 dapat diartikan bahwa besarnya kontribusi produk, harga, promosi, tempat, proses terhadap kepuasan konsumen sebesar $87,1 \%$ sedangkan sisanya sebesar 12,9 $\%$ dipengaruhi oleh variabel lain yang tidak diteliti dalam penelitian ini.

Hasil perhitungan dengan menggunakan program SPSS diperoleh nilai thitung untuk produk sebesar 3,616 lebih besar dari nilai tabel sebesar 1,684 artinya variabel produk berpengaruh terhadap nilai variabel dependen (kepuasan konsumen), ini berarti $\mathrm{Ha}$ diterima. Nilai thitung untuk harga sebesar 2,548 lebih besar dari nilai $t_{\text {tabel }}$ sebesar 1,684 artinya variabel harga berpengaruh terhadap nilai variabel dependen (kepuasan konsumen), Ha diterima . Nilai thitung untuk promosi sebesar 3,437 lebih besar dari nilai $t_{\text {tabel }}$ sebesar 1,684 artinya variabel promosi berpengaruh terhadap nilai variabel dependen (kepuasan konsumen), Ha diterima. Nilai thitung untuk tempat sebesar 1,963 lebih besar dari nilai tabel sebesar 1,684 artinya variabel tempat berpengaruh terhadap nilai variabel dependen (kepuasan konsumen), $\mathrm{Ha}$ diterima. Nilai $\mathrm{t}_{\text {hitung }}$ untuk variabel proses sebesar 1,355 lebih kecil dari 
nilai $t_{\text {tabel }}$ sebesar 1,684 artinya variabel proses tidak berpengaruh terhadap nilai variabel kepuasan konsumen.

Nilai $F_{\text {hitung }}$ dalam penelitian ini sebesar 59,469 lebih besar dari nilai $F_{\text {tabel }}$ sebesar 2,61 pada $\alpha=0,05$ ini berarti $\mathrm{Ho}$ ditolak dan $\mathrm{Ha}$ diterima. Hal ini menunjukan bahwa variabel produk, harga, promosi, tempat, proses, layanan pelanggan dan orang bersama-sama mempunyai pengaruh yang sangat signifikan terhadap kepuasan konsumen.

Berdasarkan hasil analisis diatas menunjukan variabel proses tidak signifikan terhadap kepuasan konsumen. Oleh karena itu, penulis menganalisa kembali data dengan menghilangkan variabel proses. Dari hasil analisis data dengan menggunakan program SPSS dapat dilihat dari tabel 4.8 berikut ini.

Tabel 4.8 Model 4: Hasil Analisis Regresi Linear Berganda, Uji $t_{\text {hitung, }}$ Uji $F_{\text {hitung, Koefisien }}$ Korelasi dan Determinasi.

\begin{tabular}{|c|l|c|c|c|}
\hline $\begin{array}{c}\text { Variabel } \\
\text { Terikat }(\mathrm{Y})\end{array}$ & $\begin{array}{c}\text { Variabel } \\
\text { Bebas }(\mathrm{X})\end{array}$ & Correlation & t Hitung & Coefficients \\
\hline Kepuasan & Produk & 0,805 & 3,523 & 0,328 \\
\cline { 2 - 5 } Konsumen & Harga & 0,795 & 2,274 & 0,243 \\
\cline { 2 - 5 } & Promosi & 0,837 & 3,808 & 0,362 \\
\cline { 2 - 5 } & Tempat & 0,778 & 2,373 & 0,199 \\
\hline
\end{tabular}

$\begin{array}{ll}\text { Konstanta } & :-4.054 \\ \text { R. squared } & : 0.866 \text { (Determinasi) } \\ \text { Multiple R } & : 0.930 \text { (Korelasi) } \\ \text { Fhitung } & : 72.523\end{array}$

Dari hasil analisis, diperoleh persamaan regresi linear berganda :

$Y=-4,054+0,328 \mathrm{pro}+0,243 \mathrm{hrg}+0,362 \mathrm{prm}$ $+0,199$ tpt

Korelasi antara variabel produk dengan kepuasan konsumen sangatlah signifikan, hal ini dapat dilihat dari tabel korelasi yang menunjukan angka sebesar 0,805 yang artinya, hubungan variabel produk terhadap kepuasan konsumen memiliki derajat asosiasi yang tinggi. Korelasi yang berderajat asosiasi yang tinggi juga dimiliki variabel harga, dimana hal ini ditunjukan oleh angka korelasi sebesar 0,795 . Korelasi variabel promosi yaitu angka korelasi sebesar 0,837 . korelasi yang berderajat asosiasi yang tinggi juga dimiliki oleh variabel tempat, dimana dapat dilihat angka korelasi sebesar 0,778. Korelasi (R) sebesar 0,930 yang artinya, hubungan variabel independen yaitu produk, harga, promosi dan tempat mempengaruhi variabel dependen yaitu kepuasan konsumen sebesar $93 \%$.

Untuk mengetahui besarnya kontribusi seluruh variabel bebas $(X)$ terhadap variabel kepuasan konsumen (Y), dapat dilihat dari koefisien determinasinya $\left(R^{2}\right)$. Nilai $R^{2}$ pada penelitian ini sebesar 0,866 dapat diartikan bahwa besarnya kontribusi produk, harga, promosi dan tempat terhadap kepuasan konsumen sebesar 86,6\% sedangkan sisanya sebesar $13,4 \%$ dipengaruhi oleh variabel lain yang tidak diteliti dalam penelitian ini.

Hasil perhitungan dengan menggunakan program SPSS diperoleh nilai thitung untuk produk sebesar 3,523 lebih besar dari nilai tabel sebesar 1,684 artinya variabel produk berpengaruh terhadap nilai variabel dependen (kepuasan konsumen), ini berarti $\mathrm{Ha}$ diterima. Nilai thitung untuk harga sebesar 2,274 lebih besar dari nilai $t_{\text {tabel }}$ sebesar 1,684 artinya variabel harga berpengaruh terhadap nilai variabel dependen (kepuasan konsumen), Ha diterima . Nilai thitung untuk promosi sebesar 3,808 lebih besar dari nilai $t_{\text {tabel }}$ sebesar 1,684 artinya variabel promosi berpengaruh terhadap nilai variabel dependen (kepuasan konsumen), Ha diterima. Nilai thitung untuk tempat sebesar 2,373 lebih besar dari nilai $t_{\text {tabel }}$ sebesar 1,684 artinya variabel tempat berpengaruh terhadap nilai variabel dependen (kepuasan konsumen), Ha diterima.

Nilai $F_{\text {hitung }}$ dalam penelitian ini sebesar 72,523 lebih besar dari nilai $F_{\text {tabel }}$ sebesar 2,61 pada $\alpha=$ 0,05 ini berarti Ho ditolak dan Ha diterima. Hal ini menunjukan bahwa variabel produk, harga, promosi dan tempat bersama-sama mempunyai pengaruh yang sangat signifikan terhadap kepuasan konsumen.

Pada model 1 dengan menggunakan tujuh variabel yaitu produk, harga, promosi, tempat, proses, layanan pelanggan dan orang menunjukan bahwa variabel tempat, proses, layanan pelanggan dan orang tidak berpengaruh secara signifikan terhadap kepuasan konsumen. Pada model 2, variabel orang tidak dimasukkan dalam perhitungan dan hasilnya menunjukan bahwa variabel proses dan layanan pelanggan tidak siginifikan terhadap kepuasan konsumen secara parsial. Kemudian penulis kembali menghilangkan variabel layanan pelanggan pada model 3 , dan hasilnya variabel proses tidak menunjukan nilai yang signifikan terhadap kepuasan konsumen, 
penulis kembali menghilangkan variabel proses pada model ke 4 dan memperoleh hasil bahwa keempat variabel yaitu produk, harga, promosi dan tempat menunjukan nilai yang signifikan terhadap kepuasan konsumen.

\section{KESIMPULAN DAN SARAN}

\subsection{Kesimpulan}

Bauran pemasaran jasa berpengaruh terhadap kepuasan konsumen perusahaan. Analisis statistik pada hasil penelitian model 1,2 , \& ke 3 menunjukkan bahwa produk, harga, promosi, tempat, proses, layanan pelanggan, dan orang berpengaruh terhadap kepuasan konsumen sedangkan sisanya dipengaruhi variabel lain yang tidak diteliti. Uji hipotesa menggunakan uji $t$ diperoleh nilai thitung untuk produk, harga, promosi, dan tempat lebih besar dari nilai $t_{\text {tabel, }}$ artinya keempat variabel ini berpengaruh terhadap nilai variabel kepuasan konsumen, $\mathrm{Ha}$ diterima. Nilai $F_{\text {hitung }}$ lebih besar dari nilai $F_{\text {tabel }}$ pada $\alpha=0,05$ ini berarti Ho ditolak dan Ha diterima. Hal ini menunjukan variabel produk, harga, promosi dan tempat bersama-sama berpengaruh signifikan terhadap kepuasan konsumen.

\subsection{Saran}

Perusahaan sebaiknya lebih memperhatikan dan meningkatkan pelayanan pada variabelvariabel bauran pemasaran dengan cara menyewakan produk-produk yang berkualitas, menjamin kestabilan harga agar dapat bersaing dengan perusahaan sejenis, lebih menggiatkan promosi, melakukan training bagi para karyawan dengan tujuan untuk meningkatkan kualitas pelayanan kepada konsumen.

\section{DAFTAR PUSTAKA}

Algifari. 1997. Statistika Induktif untuk Ekonomi dan Bisnis, Akademi Manajemen Perusahaan YKPN.

Alma, Buchari. 2000. Manajemen Pemasaran dan Pemasaran Jasa, Anggota Ikatan Penerbit Indonesia (IKAPI), Jawa Barat.

Cravens, David W. 1996. Pemasaran Strategis, PT. Erlangga, Jakarta.
Davey Rood, Jacks Anthony. 2001. Meningkatkan Kerja Pemasaran, Terjemahan Rizky Hendriko, Elex Media Komputindo, Jakarta.

Durianto Darmadi, Sugiarto dan Sitinjak Tony. 2001. Strategi Menaklukan Pasar, PT. Gramedia Pustaka Utama, Jakarta.

Fecikova, Ingrid, 2004, An Index Method for Measurement of Customer Satisfaction, TQM Magazine, 16(1), 57-68.

Fuad dan Sugiarto. 2001. Pengantar Bisnis, PT. Gramedia Pustaka Utama.

Hasan Iqbal. 2003. Statistik I edisi kedua, Bumi Aksara, Jakarta.

Kartajaya Hermawan (2002) Marketing Plus 2000, Siasat Memenangkan Persaingan Global, PT. Gramedia.

Keegan, W.J. 1999. Global Marketing Management, sixth edition, Prentice Hall.

Kotler, Philip dan Kevin Lane Keller (2007) Manajemen Pemasaran, edisi kedua belas, PT. Indeks, Jakarta.

Kotler, Philip dan Gary Amstrong (2003) DasarDasar Pemasaran, edisi kesembilan, PT. Indeks, Jakarta.

Payne Adrian. 2001. Pemasaran Jasa, Pearson Education Asia.

Shankar, Venkatesh, Amy K. Smith, and Arvind Rangaswamy.2003, Customer Sastifaction and Loyalty in Online and Offline Environments, International Journal of Research in Marketing, 20 (2), 153-175.

Simamora Hendry. 2000. Manajemen Pemasaran Internasional, jilid II, Salemba Empat.

Siswanto S. 1998. Kerangka Dasar Manajemen Pemasaran, LPPM Jakarta. 
Soderlund, Magnus, 2003. The Retrospective and the Prospective Mind and the Temporal Framing of Customer Satisfaction, European Journal of Marketing, 37 (10), 1375-1389.

Tjiptono Fandy. 2005. Pemasaran Jasa, Bayumedia. Jakarta.

Usmara A. 2003. Strategi Baru Manajemen Pemasaran, Amara Books.

Umar, Husein. 2002. Riset Pemasaran dan Prilaku Konsumen, PT. Gramedia.

Walker, Boyd and Larreche. 2000. Manajemen Pemasaran, Suatu Pendekatan Strategis dengan Orientasi Global, edisi kedua, PT. Erlangga.

Zikmund William G and Michael d'Amico. 1999. Marketing, South-Western College Publishing. 